\title{
Omental adipose tissue is a more suitable source of canine Mesenchymal stem cells
}

\author{
Francisca Bahamondes ${ }^{1,2^{*}}$, Estefania Flores ${ }^{2}$, Gino Cattaneo $^{2}$, Flavia Bruna ${ }^{1}$ and Paulette Conget ${ }^{1}$
}

\begin{abstract}
Background: Mesenchymal Stem Cells (MSCs) are a promising therapeutic tool in veterinary medicine. Currently the subcutaneous adipose tissue is the leading source of MSCs in dogs. MSCs derived from distinct fat depots have shown dissimilarities in their accessibility and therapeutic potential. The aims of our work were to determine the suitability of omental adipose tissue as a source of MSCs, according to sampling success, cell yield and paracrine properties of isolated cells, and compared to subcutaneous adipose tissue.

Results: While sampling success of omental adipose tissue was 100\% (14 collections from 14 donors) for subcutaneous adipose tissue it was $71 \%$ (10 collections from 14 donors). MSCs could be isolated from both sources. Cell yield was significantly higher for omental than for subcutaneous adipose tissue (38 \pm 1 vs. $30 \pm 1$ CFU-F/g tissue, $p<0.0001)$. No differences were observed between sources regarding cell proliferation potential (73 \pm 1 vs. $74 \pm 1$ CDPL) and cell senescence (at passage 10, both cultures presented enlarged cells with cytoplasmic vacuoles and cellular debris). Omental- and subcutaneous-derived MSCs expressed at the same level bFGF, PDGF, HGF, VEGF, ANG1 and IL-10. Irrespective of the source, isolated MSCs induced proliferation, migration and vascularization of target cells, and inhibited the activation of T lymphocytes.

Conclusion: Compared to subcutaneous adipose tissue, omental adipose tissue is a more suitable source of MSCs in dogs. Since it can be procured from donors with any body condition, its collection procedure is always feasible, its cell yield is high and the MSCs isolated from it have desirable differentiation and paracrine potentials.
\end{abstract}

Keywords: Mesenchymal stem cell, Source, Adipose tissue, Omentum, Canine, Dog

\section{Background}

Mesenchymal stem cells (MSCs) are non-hematopoietic precursor cells that can be differentiated, among others, into chondrocytes, osteocytes and adipocytes [1]. Together, MSCs secrete trophic, vasculogenic and immunomodulatory factors that have a paracrine effect on tissue resident cells [2-4]. Hence, MSCs are a promissory therapeutic tool for regenerative medicine [5].

The leading source of MSCs is the bone marrow. In 2001, they were isolated for the first time from adipose tissue [6]. When compared to bone marrow, adipose tissue appeared as a superior source of MSCs due to the fact that a less invasive procedure is required to procure it [7-9].

\footnotetext{
* Correspondence: fbahamondesg@ug.uchile.cl

${ }^{1}$ Centro de Medicina Regenerativa, Facultad de Medicina, Clínica Alemana Universidad del Desarrollo, Av. Las Condes 12,438, Lo Barnechea, Santiago 7710162, Chile

2Departamento de Ciencias Clínicas, Facultad de Ciencias Veterinarias y Pecuarias, Universidad de Chile, Av. Santa Rosa 11,735, Santiago, Chile
}

In veterinary medicine, it has been proven that the administration of adipose-derived MSCs have therapeutic effects in small animal patients, particularly in cats and dogs [10-13]. Adult dogs have adipose tissue locates mainly in subcutaneous and visceral depots. Thus, adipose tissue may be procured through minimally invasive procedures from arms, thighs and abdomen (subcutaneous), or from omentum, kidney and liver (visceral) [14, 15]. While the abundance of subcutaneous adipose tissue depends on the body condition, the extent of omentum is relatively constant $[16,17]$. It has been demonstrated that there are MSCs in the omentum of both dogs $[10,18]$ and humans $[19,20]$. Omentalderived MSCs are similar to subcutaneous-derived MSCs according to their proliferation and surface antigen expression [18]. Up to our knowledge, no data are available regarding the abundance and paracrine potential of omental-derived MSCs. Since previous studies showed that adipose-derived MSC properties vary from depot to 
depot [21], it will be also interesting to compare MSCs isolated form omentum with those isolated from subcutaneous fat, the leading adipose source of MSCs.

The aims of our work were to determine the suitability of omental adipose tissue as a source of MSCs, according to sampling success, cell yield and paracrine properties of isolated cells, and compared to subcutaneous adipose tissue.

\section{Methods}

\section{Collection of adipose tissue}

Fourteen female dogs of different breeds, 6-12 months old, with normal corporal condition, clinically healthy and having elective ovariohysterectomies were enrolled in the study, after client-owned provided written informed consent. Animals were pre-anesthetized with $0.04 \mathrm{mg} / \mathrm{Kg}$ Acepromazine (Holliday-Scott S.A, Buenos Aires, Argentina). General anesthesia was induced with $3 \mathrm{mg} / \mathrm{Kg}$ Propofol (Fresenius Kabi, Spain) and maintained with Isofluorane (Baxter Healthcare Corporation, Deerfield, IL). Approximately $3 \mathrm{~cm}^{3}$ (5-10 g) of omental and subcutaneous adipose tissue were procured from greater omentum and abdominal region, respectively. Subsequently, an ovariohysterectomy was performed. Muscular and skin incisions were sutured with a simple, interrupted pattern. Up to three days post-surgery animals received $1 \mathrm{mg} / \mathrm{Kg} / 24 \mathrm{~h}$ Ketoprofen (Merial Laboratorios, Argentina).

Study was approved by Ethic Committee Facultad de Ciencias Veterinarias y Pecuarias, Universidad de Chile (No. 03-2014).

Isolation, ex vivo expansion and characterization of MSCs Adipose tissue samples were weighed, washed with phosphate buffered saline (PBS. Sigma, St. Louis, MO, USA) containing $80 \mu \mathrm{g} / \mathrm{mL}$ gentamycin (Sanderson Laboratory, Santiago, Chile), minced with scissors and scalpels, and digested in PBS containing $1 \mathrm{mg} / \mathrm{mL}$ collagenase type II (Gibco, Grand Island, NY, USA), at $37{ }^{\circ} \mathrm{C}$, overnight. Enzyme activity was neutralized with alphaMEM (Gibco, Auckland, NZ) supplemented with 10\% fetal bovine serum (Gibco, Auckland, NZ) and $80 \mu \mathrm{g} / \mathrm{mL}$ gentamicin (Sanderson Laboratory, Santiago, Chile) (here after expansion medium), and centrifuged at $400 \times \mathrm{g}$ for $10 \mathrm{~min}$. Pelleted cells were resuspended in expansion medium and plated at a density of 50,000 nucleated cells $/ \mathrm{cm}^{2}$ and cultured under an atmosphere with $5 \% \mathrm{CO}_{2}$, at $37{ }^{\circ} \mathrm{C}$. Fourty eight hours later, nonadherent cells were removed by media change. When $80 \%$ confluence was achieved, adherent cells were detached with $0.25 \%$ trypsin and $2.65 \mathrm{mM}$ EDTA, centrifuged and subcultured at 5000 cells $/ \mathrm{cm}^{2}$. After two subcultures, adherent cells were characterized according to their adipogenic [21], chondrogenic [22] and osteogenic differentiation potential [23]. Although there are currently no consensus markers for canine MSCs as there are for human MSCs [1], immunophenotyping was performed by flow cytometry analysis after labeling with monoclonal antibodies against: $\mathrm{CD} 45^{\mathrm{FTC}}, \mathrm{CD} 11 \mathrm{~b}^{\mathrm{PE}-\mathrm{Cy} 5}$, $\mathrm{CD} 44^{\mathrm{APC}}$ and $\mathrm{CD} 90^{\mathrm{PE}}$ or their respective isotype controls (rat IgG2 $\mathrm{b}^{\mathrm{FICC}}$, rat IgG2 $\mathrm{b}^{\mathrm{PE}-\mathrm{Cy} 5}$, rat IgG2 $\mathrm{b}^{\mathrm{APC}}$ or rat IgG2 $\mathrm{b}^{\mathrm{PE}}$; eBioscience, San Diego, $\mathrm{CA}$ ).

\section{Fibroblast-like Colony forming unit (CFU-F) assay}

CFU-F assay was performed on freshly isolated cells as previously described [24]. Briefly, 500 mononuclear cells $/ \mathrm{cm}^{2}$ were cultured in expansion medium. At day 7 , cells were fixed with $4 \%$ paraformaldehyde for $10 \mathrm{~min}$ and stained with $0.5 \%$ crystal violet (Sigma-Aldrich, St. Louis, MO) in 10\% methanol for 20 min. Plates were observed under light microscope (Leica DM2000). Clusters containing more than 50 cells were scored as CFU-Fs and counted. Results were expressed as CFU-F per gram of tissue (CFU-F/g tissue).

Assays were performed in triplicate.

\section{Evaluation of cumulative population doubling level (CPDL) and senescence}

One thousand cells $/ \mathrm{cm}^{2}$ were seeded and cultured with expansion medium. The medium was changed every three days and cells were subcultured when reaching $80 \%$ confluence. The population doubling (PD) at each subculture was calculated according to the formula $\mathrm{PD}=\ln \left(N_{f} / N_{i}\right) / \ln 2$, where $N_{i}$ and $N_{f}$ are initial and final cell numbers, respectively. The PDs of continuous subcultures were added to obtain CPDL [10].

Senescence was assessed looking for changes in cell morphology such as cell enlargement, accumulation of vacuoles and presence of cellular debris [25].

Assays were performed in triplicate.

\section{RT-qPCR}

RNA was extracted from cells using Tryzol (Invitrogen, Carlsbad, CA, USA) and treated with DNAse (Invitrogen, Carlsbad, CA, USA) following the manufacturer's instructions. One $\mu \mathrm{g}$ of RNA was reverse-transcribed using oligo-dT primers and Moloney murine leukemia virus reverse transcriptase. The abundance of mRNA was determined by qPCR using SYBR Green Technology and canine-specific primers for bFGF, PDGF HGF, VEGF, ANG1, IDO, IL-10 and 18S (Additional file 1: Table S1). Cycling condition were: 1 cycle, $94{ }^{\circ} \mathrm{C}$ for $10 \mathrm{~min}$; 3035 cycles, $94{ }^{\circ} \mathrm{C}$ for $10 \mathrm{~min}$; optimal annealing temperature for $5 \mathrm{~min} ; 72{ }^{\circ} \mathrm{C}$ for $4 \mathrm{~min}$; 1 cycle, $64{ }^{\circ} \mathrm{C}$ for $10 \mathrm{~min} ; 1 \mathrm{cycle}, 40{ }^{\circ} \mathrm{C}$ for $30 \mathrm{~min}$. The qPCR products were separated by electrophoresis on $2 \%$ agarose gel, stained with $1 \%$ ethidium bromide and visualized under UV light. Digital images were captured with 
Alpha imagen software. Values were normalized to $18 \mathrm{~S}$ mRNA levels. Relative gene expression was quantified with the $2^{-\Delta \Delta \mathrm{Ct}}$ method [26].

\section{Proliferation assay}

Human fibroblasts were seeded at 4000 cells $/ \mathrm{cm}^{2}$ and cultivated with alpha-MEM (control) or alpha-MEM conditioned by MSCs for $24 \mathrm{~h}$. The medium was changed every 3 days. Three, six, nine and 12 days later, cells were stained with $0.5 \%$ crystal violet in $10 \%$ methanol for $20 \mathrm{~min}$. After four washes, crystal violet incorporated into the cells were solubilized with 50\% methanol in PBS and quantified spectrophotometrically (absorbance at $570 \mathrm{~nm})[24]$.

Assays were performed in triplicate.

\section{Scratch assay}

Human fibroblasts were seeded at $8000 \mathrm{cells} / \mathrm{cm}^{2}$. After $24 \mathrm{~h}$, a line in the monolayer was performed with a sterile p200 pipette tip and medium was changed by alphaMEM (control) or alpha-MEM conditioned by MSCs for $24 \mathrm{~h}$. Zero, six, and $12 \mathrm{~h}$ after scratching images were captured under a light microscope (Leica DM2000) with a digital camera (Leica DFC 295). Image J software (http://rsbweb.nih.gov/ij/) was used to quantify the scratch area [27].

Assays were performed in triplicate.

\section{Tube formation assay}

Human umbilical vein endothelial cells (HUVECs) were seeded at 3000 cells $/ \mathrm{cm}^{2}$ on $10 \mathrm{mg} / \mathrm{mL}$ growth factorreduced Matrigel (BD Biosciences, Boston, MA, USA) and exposed to alpha-MEM (control), alpha-MEM conditioned by MSCs for $24 \mathrm{~h}$ or endothelial growth medium (Lonza, Walkersville, MD, USA) (positive control) [28]. Five hours later, images were captured under a light microscope using a digital camera. WimTube program (Wimasis GmbH, Munich, Germany) was used to quantify i) total tube length, ii) total branching point, iii) total loops.

Assays were performed in triplicate.

\section{T lymphocyte proliferation assay}

Canine peripheral blood mononuclear cells were labeled with carboxyfluorescein succinimidyl ester (Invitrogen/ Molecular Probes, Eugene, OR) and cultivated with alpha-MEM (control) or alpha-MEM conditioned by MSCs for $24 \mathrm{~h}$, supplemented with $4 \mathrm{uL}$ (1:10) phytohaemaglutinin (Gibco, Invitrogen, Corporation, Scotland, UK). Five days later, cells were stained with monoclonal antibody against $\mathrm{CD} 4^{\mathrm{PE}}$ (Serotec, Kidlington, Oxford, United Kingdom) and analyzed by flow cytometry [29].

Assays were performed in triplicate.

\section{Statistical analysis}

Data are presented as mean \pm S.E.M. To determine the statistical significance of intergroup differences a oneway ANOVA test was used to compare mean values among all groups and Student's unpaired $t$-test or Mann-Whitney test (non parametric) was used to compare mean values between two groups. $p<0.05$ was considered as statistically significant.

\section{Results}

Omental adipose tissue has higher sampling success than subcutaneous adipose tissue

The age and weight of donor dogs were $10 \pm 3$ months and $12 \pm 6 \mathrm{Kg}$ (Table 1). Omental samples were procured from the 14 donors and subcutaneous samples were procured from 10 of them. Thus, the success sampling rates were $100 \%$ (14 of 14) for omental adipose tissue and $71 \%$ (10 of 14 ) for subcutaneous adipose tissue (Table 1). The average weight of the procured samples was $5.2 \pm 4.5 \mathrm{~g}$ for omental and $2.4 \pm 3.4 \mathrm{~g}$ for subcutaneal adipose tissue (Table 1 ).

Further characterization of adipose-derived MSCs was performed for samples obtained from the 10 donors in whom it was possible to obtain both omental and subcutaneous adipose tissues.

\section{Omental adipose tissue and subcutaneous adipose tissue have MSCs}

Cells isolated from both sources adhered to plastic and showed fibroblast-like morphology (Fig. 1a). Together, they were negative for hematopoietic markers (CD45 and $\mathrm{CD} 11 \mathrm{~b}$ ) and positive for MSC markers (CD90 and CD44) (Fig. 1b). When exposed to adipogenic stimulus, cells differentiated into adipocytes that accumulate lipid droplets throughout the cytoplasm as confirmed by Oil Red O staining (Fig. 1c). After 21 days under chondrogenic induction, sulfated glycosaminoglycans were present in the matrix as revealed by Safranin O staining (Fig. 1c). Cell osteogenic differentiation was confirmed due to the appearance, 3 weeks after exposure to osteogenic medium, of calcium deposits that stained with Alizarin Red (Fig. 1c).

\section{Omental adipose tissue has higher abundance of MSCs than subcutaneous adipose tissue}

The relative abundance of MSCs in omental adipose tissue was $38 \pm 1 \mathrm{CFU}-\mathrm{F} / \mathrm{g}$ tissue and in subcutaneous adipose tissue was $30 \pm 1$ CFU-F/g tissue, $p<0.0001$ (Fig. 2a-2b).

\section{MSCs derived from omental and subcutaneous adipose tissues have a similar expansion potential}

No statistical difference was observed bewteen omental- and subcutaneous-derived MSCs regarding 
Table 1 Enrolled animals and procured samples characteristics

\begin{tabular}{lllll}
\hline Donor (identifier) & Age (months) & Weight (kilograms) & Subcutaneous (grams) & Omental (grams) \\
\hline B001 & 8 & 8 & not available & 6.3 \\
P002 & 12 & 15 & 4.8 & 8.1 \\
L003 & 7 & 11 & 4.6 & 9.8 \\
P004 & 8 & 12 & not available & 3.1 \\
K005 & 12 & 15 & 1.9 & 2.3 \\
L006 & 7 & 12 & 4.5 & 8.4 \\
P007 & 8 & 10 & 3.2 & 4.5 \\
C008 & 12 & 16 & 3.1 & 7.1 \\
C009 & 11 & 6 & not available & 3.2 \\
S010 & 8 & 15 & 5.8 & 5.9 \\
O011 & 8 & 7 & not available & 3.7 \\
C012 & 12 & 10 & 3.5 \\
P013 & 10 & 6.3 & 4.8 \\
S014 & 10 & 18 & 3.3 & 3.2 \\
TOTAL & $10 \pm 3$ & $12 \pm 6$ & $2.4 \pm 3.4$ & $5.2 \pm 4.5$ \\
\hline
\end{tabular}

their proliferation potential up to passage $12(73 \pm 1$ vs. $74 \pm 1 \mathrm{CDPL}$ ) (Fig. 2c). Senescence characteristics such as cell enlargement, generation of vacuoles and presence of cellular debris were seen from passage 10 in both MSCs (Fig. 2d).

\section{MSCs derived from omental and subcutaneous adipose} tissues have similar trophic properties

Both adipose-derived MSCs expressed at the same level the trophic factors bFGF, PDGF and HGF (Fig. 3a). Accordingly, no differences were observed in their potential

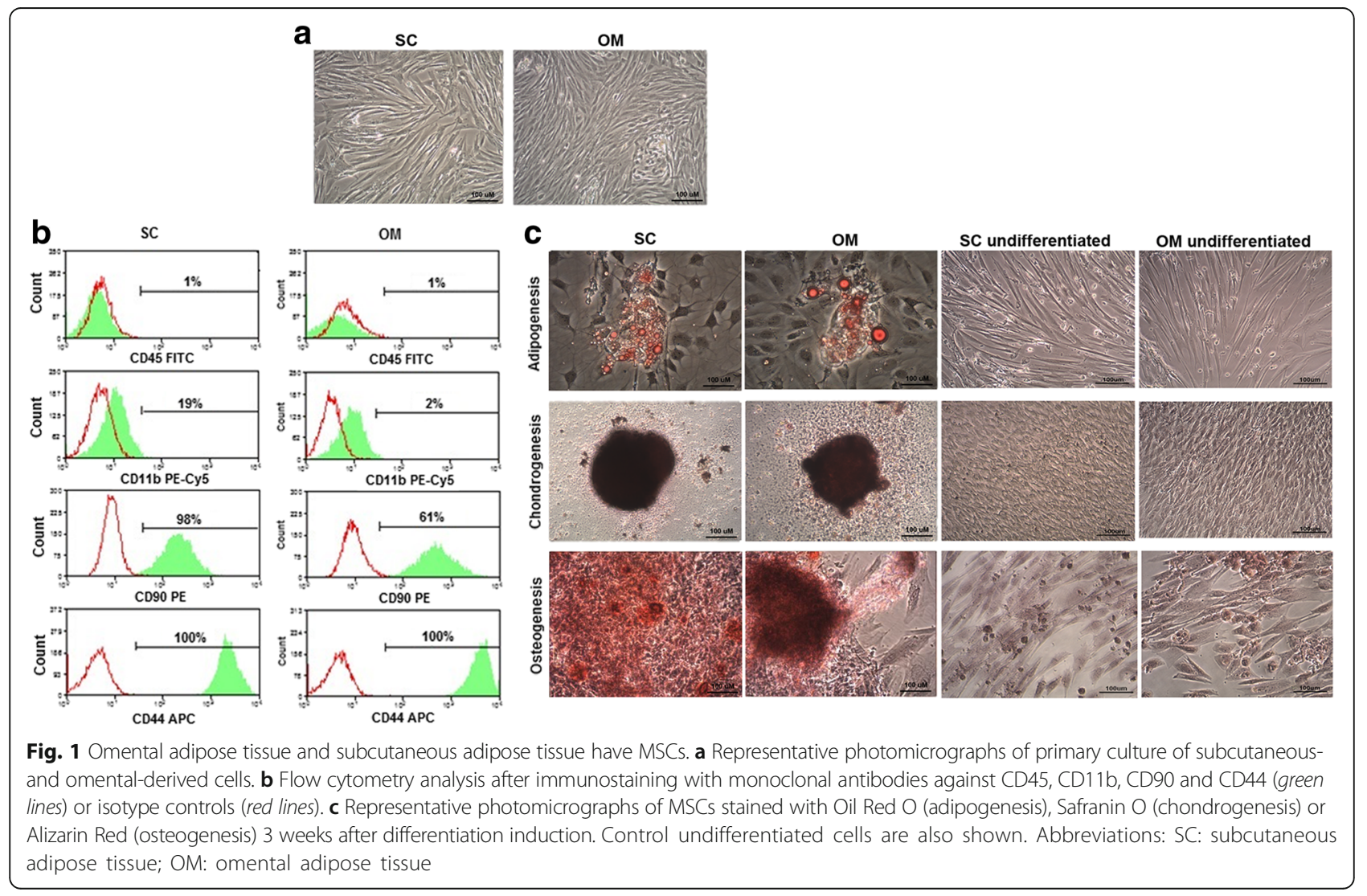




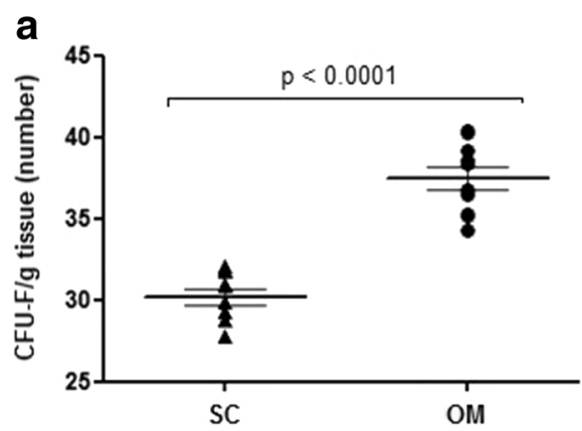

C

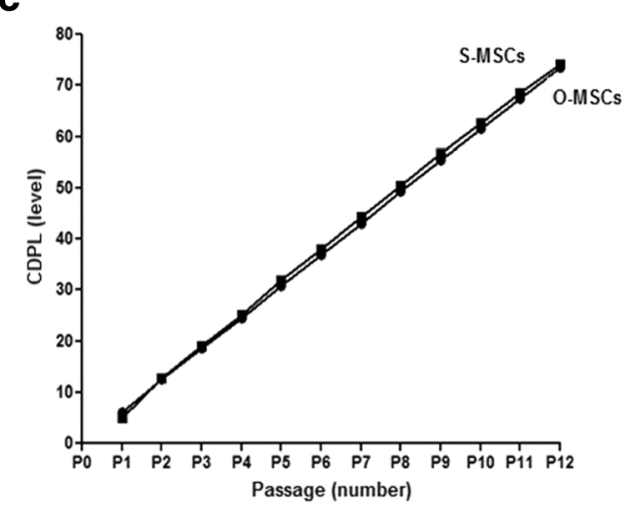

b
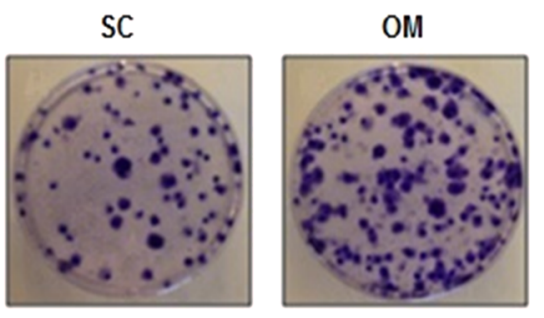

d
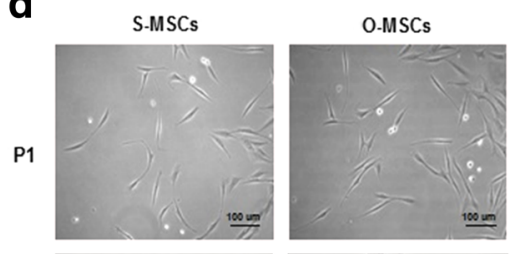

P10
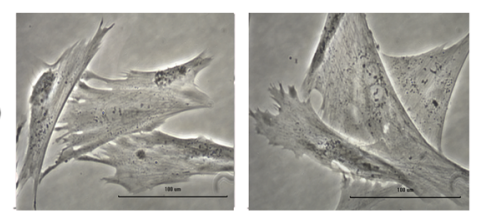

Fig. 2 Omental adipose tissue has higher abundance of MSCs than subcutaneous adipose tissue. a Quantitative analysis of CFU-Fs per gram of tissue sampled. $\mathbf{b}$ Representative photographs of plates stained with crystal violet 7 days after seeding of nucleated cells from tissue samples. c Quantitative analysis of CPDL up to passage 12. d Representative photomicrographs of S-MSCS and O-MSCs at passages 1 (P1) and 10 (P10). Abbreviations: SC: subcutaneous adipose tissue; OM: omental adipose tissue; CFU-F/g tissue: colony forming units per grams of tissue; S-MSCs: mesenchymal stem cells derived from subcutaneous adipose tissue; O-MSCs: mesenchymal stem cells derived from omental adipose tissue; CDPL: cumulative population doubling level

to promote human fibroblast proliferation and migration (Fig. 3b, c and d).

\section{MSCs derived from omental and subcutaneous adipose tissues have similar vasculogenic properties}

Irrespective of their origin, adipose-derived MSCs expressed VEGF and ANG1 (Fig. 4a). Consequently, they equally promote tube formation of HUVEC (total tube length, total branching point and total loops) (Fig. $4 \mathrm{~b}$ and c).

\section{MSCs derived from omental and subcutaneous adipose} tissues have similar immunomodulatory properties

The gene expression level of IDO was significantly lower in omental MSCs than in subcutaneous cells $(p<0.05$. Fig. 5a). The level of IL-10 did not differ significantly between them. Both adipose-derived MSCs prevent CD4+ $\mathrm{T}$ cell-proliferation at the same extent (Fig. $5 \mathrm{~b}$ ).

\section{Discussion}

A major challenge associated with MSC-based therapies is the selection of the source [14]. Here we showed in young and healthy female dogs that, compared to subcutaneous adipose tissue, omental adipose tissue is a more suitable source of MSCs. Since it can be procured from donors with any body condition, its collection procedure is always feasible, its cell yield is high and the MSCs isolated from it have desirable differentiation and paracrine potentials.

The fact that omental but not subcutaneous adipose tissue was always procurable may be attributed to volume variability of fat depots as well as to the expertise of the professional that procures them. In a study with 1265 dogs, it was shown that the size of collected samples was determined by the location of the adipose tissue, being visceral samples bigger than subcutaneous ones [12]. This difference might be critical when donor should be an emaciated patient due to either a chronic or a nutritional disease.

We showed that omental adipose tissue yielded a higher number of viable MSCs per gram of tissue than subcutaneous adipose tissue. These results are in agreement with other studies showing the same differences in humans [14] and dogs [10, 15].

Consistent with the results reported for human MSCs, canine MSCs isolated either from omental or 


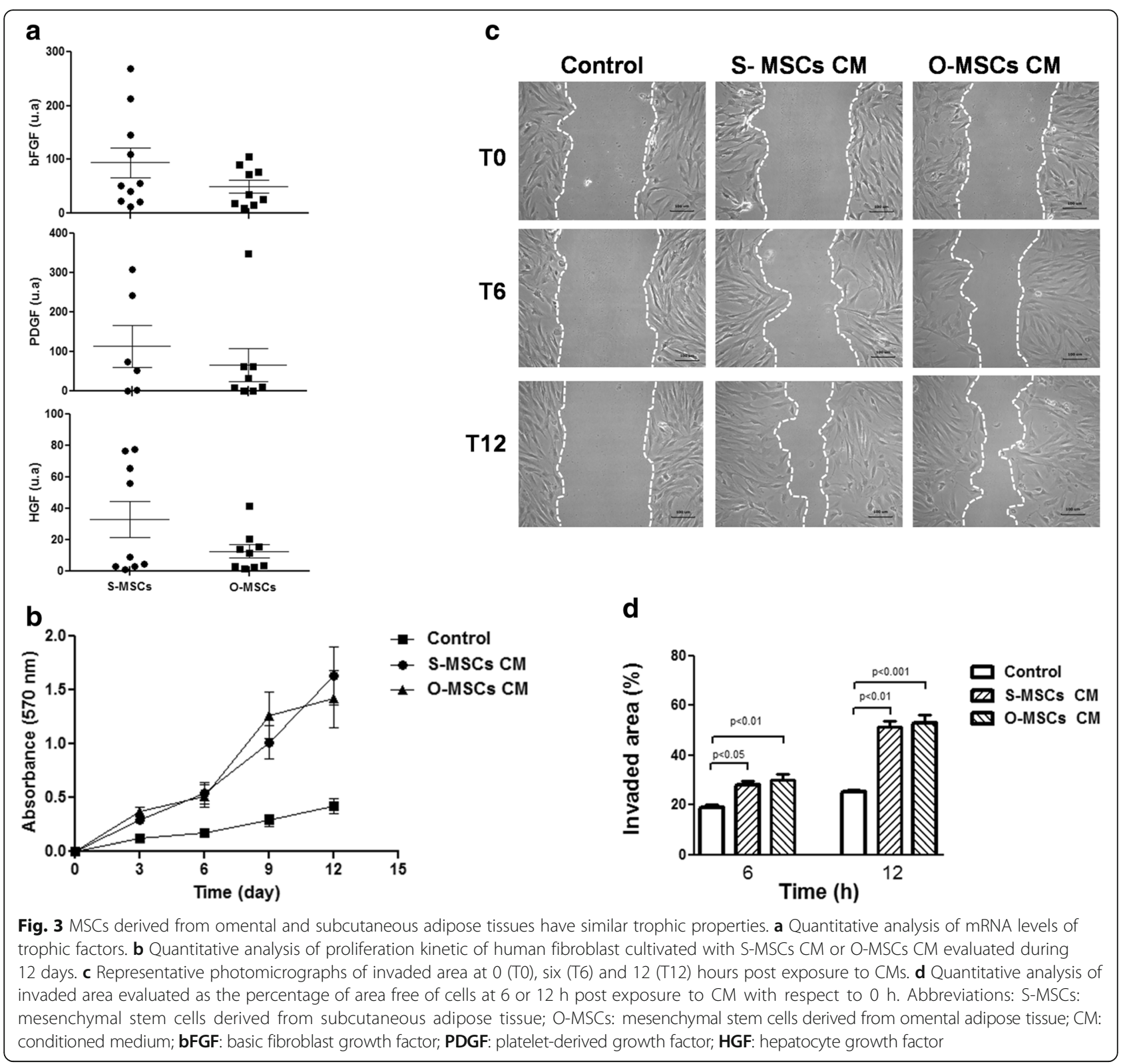

subcutaneous adipose tissue followed a lineal trend of proliferation up to passage 12 and senescence characteristics appeared at passage $10[23,30]$. Thus, our data support a significant but limited expansion potential of canine MSCs. Hence, the feasibility to be procured and the cell richness of the sample take higher relevance in order to choose the best source of canine MSCs.

The secretory activity of MSCs favors a regenerative microenvironment [31, 32]. The trophic properties of MSCs depend on the secretion of growth factors that induce cell proliferation and migration [33-35]. We showed that canine MSCs isolated from omental or subcutaneous tissues express bFGF, PDGF and HGF. Both bFGF and PDGF elicit target cell proliferation after ligand-binding induction of receptor oligomerization, activation of intrinsic receptor tyrosine kinase and phosphorylation of specific residues in the cytoplasmic region [36-39]. HGF is a pleiotropic factor displaying mitogenic, motogenic, morphogenetic, and antiapoptotic activities in different target cells [40]. Indeed, HGF promotes hepatocytes, keratinocytes, renal tubule cell and endothelial cell proliferation, dissociation of epithelial cell colonies, cell motility, and invasion through extracellular matrix. More recently, it has been shown that bFGF, PDGF and HGF can induce biological responses also on MSCs [41-43]. Our functional studies showed that, irrespective of the source, canine MSCs secrete active mitogenic and motogenic factors. 

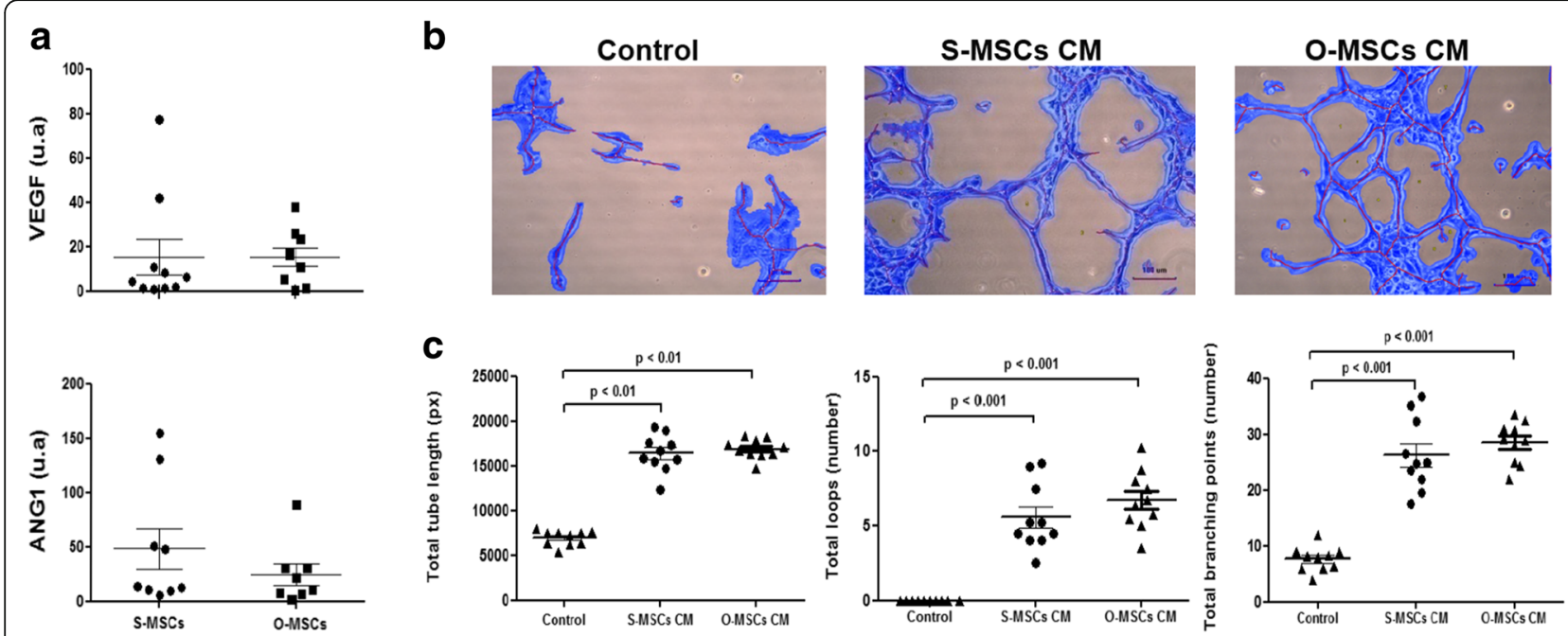

Fig. 4 MSCs derived from omental and subcutaneous adipose tissues have similar vasculogenic properties. a Quantitative analysis of mRNAs levels of vasculogenic factors. $\mathbf{b}$ Representative photomicrographs of tube assay performed with 3D collagen-embedded human umbilical endothelial cells cultivated $5 \mathrm{~h}$ with S-MSCs CM or O-MSCs CM and analyzed by Wimasis software. c Quantitative analysis of total tube length, total branching point and total loops of tube assay among the different conditions. Abbreviations: S-MSCs: mesenchymal stem cells derived from subcutaneous adipose tissue; O-MSCs: mesenchymal stem cells derived from omental adipose tissue; CM: conditioned medium; VEGF: vascular endothelial growth factor; ANG1 angiopoietin 1

Vasculogenesis is a crucial step in the wound healing process $[44,45]$. The formation of new blood vessels is necessary to sustain the newly formed granulation tissue and the survival of keratinocytes. In this study, we found that adipose tissue derived MSCs express VEGF and ANG1. Both stimulate endothelial cell proliferation, migration, and organization into tubules [46, 47]. Our functional study showed that MSCs either form omental or subcutaneous tissue secreted active factors that promote vasculogenesis.

Since in the functional assays we used human fibroblasts or human endothelial cells as target cells, our data a
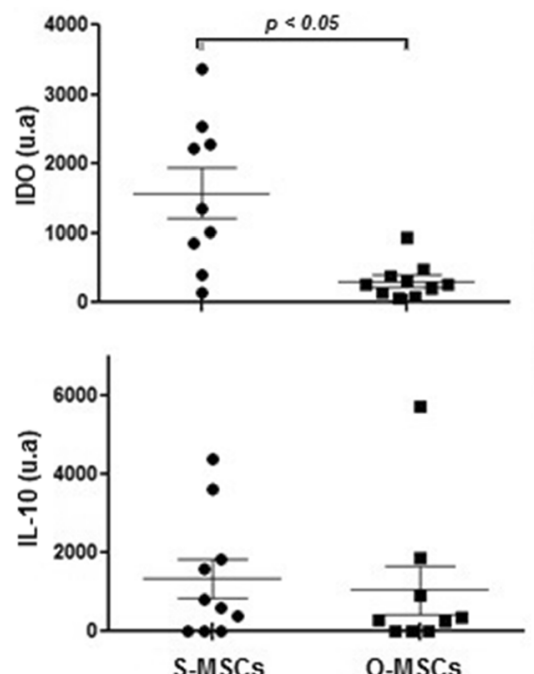

b

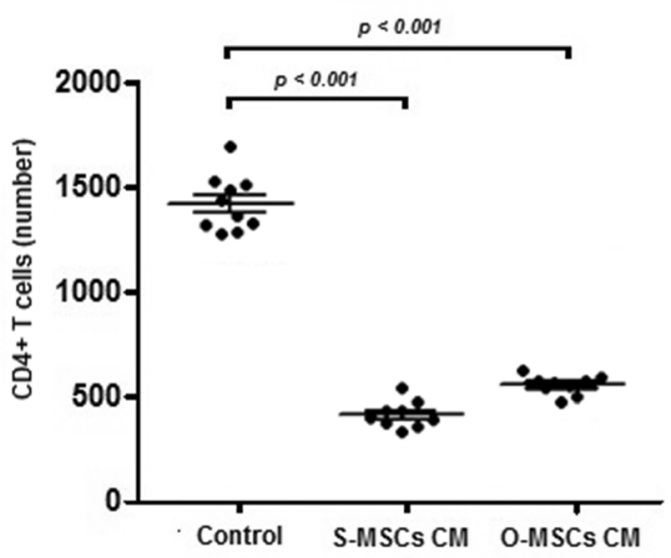

Fig. 5 MSCs derived from omental and subcutaneous adipose tissues have similar immunomodulatory properties. a Quantitative analysis of the mRNAs levels of immunomodulatory factors. Each value was normalized to $18 \mathrm{~S}$ expression. $\mathbf{b}$ Quantitative analysis of total CD4+ T-cells stimulated and cultivated with S-MSC CM and O-MSC CM after 5 days. Abbreviations: S-MSCs: mesenchymal stem cells derived from subcutaneous adipose tissue; O-MSCs: mesenchymal stem cells derived from omental adipose tissue; CM: conditioned medium; IDO indoleamine-pyrrole 2,3-dioxygenase; IL-10 interleukin 10 
prove than trophic and vasculogenic factors secreted by MSCs isolated from dog omental or subcutaneous adipose tissue overcome species-specificity barrier. In order to further characterize the products secreted by canine MSCs it would be relevant to perform the functional experiments using target cells from dogs and other species.

Much attention has been paid to the immunomodulatory properties of MSCs. Several studies have shown a paracrine suppressive effect on T cells, B cells, monocytes and macrophages [48-50]. We showed similar gene expression levels of IL-10 in MSCs from both sources studied. Though, the expression of IDO in MSCs derived from subcutaneous adipose tissue was 11fold higher than in MSCs derived from omentum. IDO catalyzes the conversion of tryptophan to kynurenine and inhibits $\mathrm{T}$ cell proliferation due to tryptophan depletion [51]. Nevertheless, this is not the unique mechanism supporting the immunosuppresive potential of MSCs [52-55]. That should explain why, despite of the differences observed in IDO mRNA levels, in the functional assay MSCs from both sources inhibit at the same magnitude CD4+ T cell proliferation. Our results appear consistent with previous findings for human and canine MSCs $[4,56,57]$.

Data here presented not only shall be useful for evidence based-selection of MSC source but also to expand the frontiers of the use of canine MSCs as they prove to produce active trophic, vasculogenic and immunomodulator soluble factors.

\section{Conclusion}

Compared to subcutaneous adipose tissue, omental adipose tissue is a more suitable source of MSCs in dogs. Since it can be procured from donors with any body condition, its collection procedure is always feasible, its cell yield is high and the MSCs isolated from it have desirable differentiation and paracrine potentials.

\section{Additional file}

Additional file 1: Table S1. Genes, primers and amplicon

characteristics. (TIFF $552 \mathrm{~kb}$ )

\footnotetext{
Abbreviations

ANG1: Angiopoietin 1; bFGF: Basic fibroblast growth factor; CDPL: Cumulative population doubling level; CFU-F: Fibroblastic-like colony forming unit; CM: Conditioned medium; EDTA: Ethylenediaminetetraacetic acid; HGF: Hepatocyte growth factor; HUVEC: Human umbilical vein endothelial cells; IDO: Indoleamine-pyrrole 2,3-dioxygenase; IL-10: Interleukin 10; MSCs: Mesenchymal stem cells; OM: Omental adipose tissue; OMSCs: Omental mesenchymal stem cells; PBS: Phosphate-buffered saline; PDGF: Platelet-derived growth factor; SC: Subcutaneous adipose tissue; SMSCs: Subcutaneous mesenchymal stem cells; VEGF: Vascular endothelial growth factor
}

\section{Acknowledgements}

We thank the dog owners for their disposition to participate in this study. Also, we are grateful with the people that work at the Center of Regenerative Medicine, Facultad de Medicina Clinica Alemana - Universidad del Desarrollo for their technical assistance.

This study was presented in part as an abstract at the International Society for Stem Cell Research Annual Meeting, Stockholm, june 2015.

\section{Funding}

This study was supported by CONICYT Grant No. 21110863 and by CONICYT Doctoral Scholarship to FB.

\section{Availability of data and materials}

All data supporting our findings are included in the manuscript. If readers need additional information they will be provided by the corresponding author (francisca.bahamondes@gmail.com).

\section{Authors' contributions}

FB designed the study, performed the experiments, analyzed data and wrote the manuscript. EF and GC participated in animal management and adipose tissue sampling. FBr performed RT-qPCR. PC designed the study, supervised all procedures, analyzed data and revised the manuscript versions. All authors read and approved the final manuscript.

\section{Competing interests}

The authors declare that they have no competing interests.

\section{Consent for publication \\ Not applicable.}

\section{Ethics approval and consent to participate}

Study was approved by Ethic Committee Facultad de Ciencias Veterinarias y Pecuarias, Universidad de Chile (No. 03-2014).

All dog owners gave written informed consent before animals enter in the study.

\section{Publisher's Note}

Springer Nature remains neutral with regard to jurisdictional claims in published maps and institutional affiliations.

Received: 31 December 2015 Accepted: 8 May 2017

Published online: 08 June 2017

\section{References}

1. Dominici M, Le Blanc K, Mueller I, Slaper-Cortenbach I, Marini F, Krause D, Deans R, Keating A, Prockop DJ, Horwitz E. Minimal criteria for defining multipotent mesenchymal stromal cells. The International Society for Cellular Therapy position statement. Cytotherapy. 2006:8:315-7.

2. Le Blanc K, Tammik L, Sundberg B, Haynesworth SE, Ringdén O. Mesenchymal stem cells inhibit and stimulate mixed lymphocyte cultures and mitogenic responses independently of the major histocompatibility complex. Scand J Immunol. 2003;57:11-20.

3. Caplan Al, Dennis JE. Mesenchymal stem cells as trophic mediators. J Cell Biochem. 2006;98:1076-84.

4. Kang JW, Kang KS, Koo HC, Park JR, Choi EW, Park YH. Soluble factorsmediated immunomodulatory effects of canine adipose tissue-derived mesenchymal stem cells. Stem Cells Dev. 2008;17:681-93.

5. Sutton MT, Bonfield TL. Stem cells: innovations in clinical applications. Stem Cells Int. 2014; doi:10.1155/2014/516278.

6. Zuk PA, Zhu M, Ashjian P, De Ugarte DA, Huang Jl, Mizuno H, Alfonso ZC, Fraser JK, Benhaim P, Hedrick MH. Human adipose tissue is a source of multipotent stem cells. Mol Biol Cell. 2002;13:4279-95.

7. Strem BM, Hicok KC, Zhu M, Wulur I, Alfonso Z, Schreiber RE, Fraser JK, Hedrick MH. Multipotential differentiation of adipose tissue-derived stem cells. Keio J Med. 2005;54:132-41.

8. Baer PC, Geiger H. Adipose-derived mesenchymal stromal/stem cells: tissue localization, characterization, and heterogeneity. Stem Cells Int. 2012;812693

9. Reich CM, Raabe O, Wenisch S, Bridger PS, Kramer M, Arnhold S. Isolation, culture and chondrogenic differentiation of canine adipose tissue- and bone marrow-derived mesenchymal stem cells-a comparative study. Vet Sci Commun. 2012;36:139-48. 
10. Neupane M, Chang C-C, Kiupel M, Yuzbasiyan-Gurkan V. Isolation and characterization of canine adipose-derived mesenchymal stem cells. Tissue Eng. 2008;14:1007-15.

11. Vieira N, Brandalise V, Zucconi E, Secco M, Strauss B, Zatz M. Isolation, characterization, and differentiation potential of canine adipose-derived stem cells. Cell Transplant. 2010;9:279-89.

12. Astor D, Hoelzler M, Harman R, Bastian R. Patient factors influencing the concentration of stromal vascular fraction (SVF) for adipose-derived stromal cell (ASC) therapy in dogs. Canine J Vet Res. 2013;77:177-82.

13. Trzil JE, Masseau I, Webb TL, Chang CH, Dodam JR, Liu H, Quimby JM, Dow SW, Reinero CR. Intravenous adipose-derived mesenchymal stem cell therapy for the treatment of feline asthma: a pilot study. J Feline Med Surg. 2015; doi:10.1177/1098612X15604351.

14. Russo V, Yu C, Belliveau P, Hamilton A, Flynn LE. Comparison of human adipose-derived stem cells isolated from subcutaneous, omental, and intrathoracic adipose tissue depots for regenerative applications. Stem Cells Transl Med. 2014;2:206-17.

15. Guercio A, Di Bella S, Casella S, Di Marco P, Russo C, Piccione G. Canine mesenchymal stem cells (MSCs): characterization in relation to donor age and adipose tissue-harvesting site. Cell Biol Int. 2013;37:789-98.

16. Thengchaisri N, Wutthiwong T, Kaewmokul S, Sastravaha A. Abdominal obesity is associated with heart disease in dogs. BMC Vet Res. 2014;10:131.

17. Kobatashi T, Koie H, Kusumi A, Kitagawa M, Kanayama K, Otsuji K Comparative investigation of body composition in male dogs using $C T$ and body fat analysis software. J Vet Med Sci. 2014;76:439-46.

18. Requicha JF, Viegas CA, Albuquerque CM, Azevedo JM, Reis RL, Gomes ME. Effect of anatomical origin and cell passage number on the stemness and osteogenic differentiation potential of canine adipose-derived stem cells. Stem Cell Rev. 2012;8:1211-22.

19. García-Gómez I, Goldsmith H, Angulo J, Prados A, López-Hervás P, Cuevas B, Dujovny M, Cuevas P. Angiogenic capacity of human omental stem cells. Neurogical Res. 2005;27:807-11.

20. Jung S, Kleineidam B, Kleinheinz J. Regenerative potential of human adipose-derived stromal cells of various origins. J Craniomaxillofac Surg. 2015;43:2144-51.

21. Contador D, Ezquer F, Espinosa M, Arango-Rodriquez M, Puebla C, Sobrevia $L$, Conget $P$. Dexamethasone and rosiglitazone are sufficient and necessary for producing functional adipocytes from mesenchymal stem cells. Exp Biol Med (Maywood). 2015;240:1235-46

22. Vellasamy S, Sandrasaigaran P, Vidyadaran S, George E, Ramasamy R. Isolation and characterisation of mesenchymal stem cells derived from human placenta tissue. World J Stem Cells. 2012;4(6):53-61.

23. Conget PA, Minguell JJ. Phenotypical and functional properties of human bone marrow mesenchymal progenitor cells. J Cell Physiol. 1999;181(1):67-73.

24. Ezquer FE, Ezquer ME, Simon V, Conget $P$. The antidiabetic effect of MSCs in not impaired by insulin prophylaxis and is not improved by second dose of cells. PLoS One. 2011; doi:10.1371/journal.pone.0016566.

25. Wagner W, Horn P, Castoldi M, Diehlmann A, Bork S, Saffrich R, Benes V, Blake J, Pfister S, Eckstein V, Ho AD. Replicative senescence of mesenchymal stem cells: a continuous and organized process. PLoS One. 2008; doi:10. 1371/journal.pone.0002213.

26. Livak KJ, Schmittgen TD. Analysis of relative gene expression data using realtime quantitative PCR and the 2(-Delta Delta C(T)). Method. 2001;25:402-8.

27. Jing L, Rui W, Lei Y, Qi W, Qinwan W, Zhengchao N, Yongchun Y, Ji M, Qiuhui P. Knochdown of nestin inhibits proliferation and migration of colorectal cancer cells. Int J Clin Exp Pathol. 2015;8:6377-86.

28. Ponce ML. Tube formation: an in vitro matrigel angiogenesis assay. Methods Mol Biol. 2009;467:183-8

29. Yoo KH, Jang IK, Lee MW, Kim HE, Yang MS, Eom Y, Lee JE, Kim YJ, Yang SK, Jung HL, Sung KW, Kim CW, Koo HH. Comparison of immunomodulatory properties of mesenchymal stem cells derived from adult human tissues. Cell Immunol. 2009;259:150-6.

30. Gruber HE, Somayaji S, Riley F, Hoelscher GL, Norton HJ, Ingram J. Human adipose-derived mesenchymal stem cells: serial passaging, doubling time and cell senescence. Biotech Histochem. 2012;87:303-11.

31. Murphy MB, Moncivais K, Caplan Al. Mesenchymal stem cells: environmentally responsive therapeutics for regenerative medicine. Exp Mol Med. 2013; doi:10.1038/emm.2013.94

32. Haynesworth SE, Baber MA, Caplan Al. Cytokine expression by human marrow-derived mesenchymal progenitor cells in vitro: effects of dexamethasone and IL-1 alpha. J Cell Physiol. 1996;166:585-92.
33. Nalldijk $Y$, Johnson AA, Ishak S, Meisel HJ, Hohaus C, Stolzing A. Migrational changes of mesenchymal stem cells in response to cytokine, growth factors, hypoxia and aging. Exp Cell Res. 2015;338:97-104.

34. Kilroy GE, Foster SJ, Wu X, Ruiz J, Shrwood S, Heifetz A, Ludlow JW, Stricker DM, Potiny S, Green P, Halvorsen YD, Cheatham B, Storms RW, Gimble JM. Cytokine profile of human adipose-derived stem cells: expression of angiogenic, hematopoietic, and pro-inflammatory factors. J Cell Physiol. 2007;212(3):702-9.

35. Antoniades $\mathrm{H}$, Scher C, Stiles C. Purification of human platelet-derived growth factor. Proc Natl Acad Sci U S A. 1979;76:1809-13.

36. Claesson-Welsh L, Ronnstrand L, Heldin C. Biosynthesis and intracellular transport of the receptor for platelet-derived growth factor. Proc Natl Acad Sci U S A. 1987;84:8796-800.

37. Heldin C. Platelet-derived growth factor-an introduction. Cytokine Growth Factor Rev. 2004;15:195-6.

38. Lubinus M, Meier K, Smith E, Gause K, LeRoy E, Trojanowska M. Independent effects of platelet-derived growth factor isoforms on mitogen-activated protein kinase activation and mitogenesis in human dermal fibroblasts. J Biol Chem. 1994;269:9822-5.

39. Walker T, Moore S, Lawson M, Panettieri R, Chilvers E. Platelet-derived growth factor-BB and thrombin activate phosphoinositide 3-kinase and protein kinase B: role in mediating airway smooth muscle proliferation. Mol Pharmacol. 1998:54:1007-15.

40. Bottaro DP, Rubin JS, Faletto DL, et al. Identification of the hepatocyte growth factor receptor as the c-met proto-oncogene product. Science. 1991:251:802-4.

41. Schuldiner M, Yanuka O, Itskovitz-Eldor J, Melton DA, Benvenisty N. Effects of eight growth factors on the differentiation of cells derived from human embryonic stem cells. Proc Natl Acad Sci U S A. 2000;97:11307-12.

42. Neuss $\mathrm{S}$, Becher $\mathrm{E}$, Woltje M, Tietze $\mathrm{L}$, Jahnen-Dechent W. Functional expression of HGF and HGF receptor/c-met in adult human mesenchymal stem cells suggests a role in cell mobilization, tissue repair and wound healing. Stem Cells. 2004;22:405-14.

43. Forte G, Minieri M, Cossa P, Antenucci D, Sala M, Gnocchi V, Fiaccavento R, Carotenuto F, De Vito P, Baldini PM, Prat M, Di Nardo P. Hepatocyte growth factor effects on Mesenchymal stem cells:proliferation, migration, and differentiation. Stem Cells. 2006:24:23-33.

44. Arnold F, West DC. Angiogenesis in wound healing. Pharmacol Ther. 1991; 52:407-22.

45. Fam NP, Verma S, Kutryk M, Stewart DJ. Clinician guide to angiogenesis. Circulation. 2003;108:2613-8.

46. Chen L, Tredget EE, Wu PYG, Wu Y. Paracrine factors of mesenchymal stem cells recruit macrophages and endothelial lineage cells and enhance wound healing. PLoS One. 2008; doi:10.1371/journal.pone.0001886.

47. Pikula M, Langa P, Kosikowska P, Trzonkowski P. Stem cells and growth factors in wound healing. Postepy Hig Med Dosw. 2015;69:874-85.

48. Keating A. How do mesenchymal stromal cells suppress T cells? Cell Stem Cell. 2008;2:106-8.

49. Le Blanc K, Mougiakakos D. Multipotent mesenchymal stromal cells and the innate immune system. Nat Rev Immunol. 2012;12:383-96.

50. English K, Mahon BP. Allogeneic mesenchymal stem cells: agents of immune modulation. J Cell Biochem. 2011;112:1963-8.

51. Munn DH, Zhou M, Attwood JT, Bondarev I, Conway SJ, Marshall B, Brown C, Mellor AL. Prevention of allogeneic fetal rejection by tryptophan catabolism. Science. 1998:281:1191-3.

52. Chinnadurai R, Copland IB, Patel SR, Galipeau J. IDO-independent suppression of T cell effector function by IFN- $\gamma$-licensed human mesenchymal stromal cells. J Immunol. 2014;192:1491-501.

53. Yan Z, Zhuansun Y, Chen R, Li J, Ran P. Immunomodulation of mesenchymal stromal cells on regulatory $T$ cells and its possible mechanism. Exp Cell Res. 2014:15:65-74.

54. Bloom DD, Centanni JM, Bhatia N, Emler CA, Drier D, Leverson GE, McKenna DH Jr, Gee AP, Lindblad R, Hei DJ, Hematti P. Cytotherapy. 2015;17:140-51.

55. Selleri S, Dieng MM, Nicoletti S, Louis I, Beausejour C, Le Deist F, Haddad E. Cordblood-derived mesenchymal stromal cells downmodulate CD4+ T-cell activation by inducing IL-10-producing Th1 cells. Stem Cells Dev. 2013;22:1063-75.

56. Ren G, Su J, Zhang L, Zhao X, Ling W, L'huillie A, Zhang J, Lu Y, Roberts Al, Ji W, Zhang $H$, Rabson AB, Shi Y. Species variation in the mechanisms of mesenchymal stem cell-mediated immunosuppression. Stem Cells. 2009;27:1954-62.

57. Keating A. Cell how do mesenchymal stromal cells suppress T cells? Stem Cell. 2008;2:106-8. 